\author{
Agnieszka Kłysik-Uryszek \\ University of Lodz \\ Faculty of Economic and Sociology \\ Institute of Economics \\ Department of International Trade \\ e-mail: agnieszka.klysik@uni.lodz.pl
}

\title{
The gender pay gap and women in managerial positions: V4 countries in the light of the European Union
}

\begin{abstract}
This research investigates the level of the gender pay gap and gender parity in the Visegrad Group countries in light of the changes that took place in the whole EU during the last decade. The following hypotheses accompany the research objective: (1) the level of the gender pay gap diminished significantly over the last decade in the V4 economies; (2) the V4 countries are following a path to achieve gender parity. Data were taken from Eurostat. The pay gap and the managerial occupations indicators were used to verify the research hypotheses.

The empirical investigation did not let us reject the first hypothesis for Poland only. However, it should be rejected for the other V4 economies. In addition, the second hypothesis should be rejected.
\end{abstract}

Keywords: Gender, pay gap, women, V4, EU

JEL Classification: J16, E24

\section{Introduction}

Gender gap equalization is a pillar of modern society. It covers, among others, the gender pay gap, which can be defined as the difference in salaries of men and women who have the same positions. In addition, the percentage of women in 
managerial positions is a crucial index of the gender gap. We should remember that promotion of gender equality is one of the Sustainable Development Goals.

This research investigates the level of the gender pay gap (GPG) and gender parity in the Visegrad countries (i.e., Czechia, Hungary, Poland, and Slovakia; hereinafter V4) in light of the changes in the EU during the last decade. The following hypotheses accompany the research objective: (1) the gender pay gap shrank significantly over the last decade in the V4 economies; (2) the V4 countries finally achieved gender parity. Data were taken from Eurostat. The pay gap and the managerial occupations indicators were used to verify the research hypotheses.

The article consists of the following parts: after the introduction, the theoretical background and the literature review are presented. These parts are followed by the methodology, data, and empirical investigation. The crucial outcomes are shown in the summary.

\section{Theoretical background and literature review}

Equalizing the gender gap, including the gender pay gap and the equal treatment of women and men, are pillars of modern societies. It has been investigated over the last few decades and is well recognized in the literature (see, e.g., Becker, 1957; Becker, 1985; Black and Brainerd, 2004). The promotion of gender equality is one of the Sustainable Development Goals (see: https://www.un.org/sustainable development/), which is why the gender gap is often analyzed in the context of sustainable development (Domańska, Żukowska \& Zajkowski, 2019), for different times, countries, and regions (see, e.g., Marilyn \& Olawale, 2017; Bando, 2019; Norrander, 1999), including the EU economies (Fadoš \& Bohdalová, 2019; Marcu \& Tănase, 2018; Dolado, García-Peñalosa \& Tarasonis, 2020), and of course Poland. In Poland, the gender gap has been investigated in the context of the policymaking process (Jakubowska \& Kaniasty, 2015) or the benevolence and hostility directed at men and women (Zawisza, Luyt \& Zawadzka, 2012), among others. The gender pay gap was also investigated (Oczki, 2016).

Not only was the gender gap measured, but some recommendations concerning different ways to reduce it were proposed (e.g., Ofisi and Lukamba, 2020). There is also an analysis of formal actions undertaken towards gender equality presented in the literature (North, 2010).

The gender pay gap can be defined as the difference in salaries of men and women with the same positions, and it has also been investigated in the literature (see, e.g., Bergmann, 1974; Blau, 1977; Bayard, Hellerstein, Neumark \& Troske, 1999). It was analyzed for Europe (Maume, Heymann \& Ruppanner, 2019; AláezAller, Longás-García \& Ullibarri-Arce, 2011; Arulampalam, Booth \& Bryan, 2007), the US (Srinivas, 2007; Blau \& Kahn, 2007), and South Africa (Adelekan \& Bussin, 2018; Bhorat \& Goga, 2013), among others. According to Eurostat, women in the EU are less present in the labor market than men. Thus, the gender 
employment gap exists and is significant. However, there are differences between EU economies (The gender pay gap situation in the EU, 2020).

The percentage of women in managerial positions is a crucial index of the gender gap, and it has also been investigated in the literature (see, e.g., van Mensvoort, Kraaykamp, Meuleman \& van den Brink, 2020; Galy-Badenas and Croucher, 2016). What is particularly interesting is that, according to Eurostat, the largest share of women in managerial positions was recorded in Latvia (45\%) and Poland (44\%). Bulgaria, Hungary, and Slovenia followed - all with 42\% (Women remain outnumbered in management, 2020). It turns out that it is not the old EU countries but the new member states that are the leaders in the percentage of women in managerial positions.

The above situation prompts a detailed analysis of the gender pay gap level and women's employment in managerial positions in recent years in the V4 economies against the background of the whole European Union. It is obvious, however, that the above-mentioned indicators do not represent a holistic approach. For instance, they neither address nor explain any qualitative inequalities in the labor market. However, being aware of these shortcomings, we decided to focus on these qualitative, calculative, and internationally comparable indexes to build a background for future, more detailed research.

\section{Research method and data}

Data were taken from the Eurostat databases, which makes the research comparable in time and space. The analysis covers yearly data between 2010 and 2020, allowing us to investigate the changes in the gender pay gap and the share of women in managerial positions over the last decade.

Two different indicators were used in this research. The first one is the unadjusted gender pay gap (see: Leythienne \& Ronkowski, 2018), which describes the difference between the salaries of men and women in a given economy and a given period. More specifically, this indicator combines gender differences in earnings, for the same work (or work of equal value), with the impact of differences in the average characteristics of men and women in the labor market. It can be calculated as follows:

$$
u G P G=\frac{A-B}{A}
$$

where:

$u G P G$ - the unadjusted gender pay gap,

$A$ - the mean gross hourly earnings of men,

$B$ - the mean gross hourly earnings of women.

This indicator is a subject for further, detailed decompositions (Leythienne \& Ronkowski, 2018). 
We are aware that the Gender Pay Gap (as a quantitative method) does not explain the causes of the wage gap between men and women. We are also aware that, to a certain extent, we have simplified the recognition of the anachronistic nature of the qualitative differences. Simultaneous qualitative studies should support the outcomes of the GPG. They could focus on the occupational availability of both genders or the social roles assigned to them. However, we decided to use the GPG as it provides data on the size of the existing gender differences between the salaries of men and women. Additionally, as they are easy to interpret, they could be a subject for international comparisons in time and space.

The second indicator is access to managerial occupations (AMO), defined as the percentage of women executive positions as a share of all employed people in that group. The AMO indicator supports the outcomes of the GPG and makes the analysis more comprehensive. It can be calculated as follows:

$$
A M O=\frac{C}{D}
$$

where:

$A M O$ - access to managerial occupations,

$C$ - the number of managerial positions occupied by women,

$D$ - the number of total managerial positions.

Decompositions of these indicators for different ages for Poland and the EU average were used in the empirical study. Additionally, we conducted detailed research on every EU member state for 2010 and 2020 to investigate the changes in the whole of the EU in the field of gender (in)equality. Additionally, simple statistical measures were used to formally describe the empirical results: the average, standard deviation, and the coefficient of variation.

\section{Empirical investigation}

The empirical investigations started by analyzing the gender pay gap in all EU economies (including the UK) for 2010 and 2019. The average data for the whole EU and the eurozone were also analyzed. The details are presented in Table 1, which contains data on the difference in the salaries of women and men (in percent) of each country. The ranking position of each economy is also shown.

The average gender pay gap decreased in the EU (and in the eurozone) by 1.7 percentage points (and $2.1 \mathrm{pp}$. in the eurozone), which is undoubtedly a positive change. However, the differences among particular countries were enormous. In 2010 , the lowest pay gap was observed in Slovenia - only $0.9 \%$, while in 2019 , the most equal earnings were noticed in Luxembourg, where women earned $1.3 \%$ less than men. The worst situation was detected in Estonia, where the GPG reached almost $28 \%$ in 2010 and $22 \%$ in 2019.

What is particularly surprising is that, generally, the differences among the EU economies increased. The standard deviation value for 2010 was $6.5 \mathrm{pp}$., rising to 
$8.2 \mathrm{pp}$. The coefficient of variation increased from $45 \%$ of the average GPG in 2010 to $63 \%$. The gender pay gap in the EU was characterized by strong (and rising) variation in the investigated period.

Table 1. The Gender Pay Gap in EU Economies in 2010 and 2019

\begin{tabular}{|c|c|c|c|c|c|c|}
\hline & \multicolumn{2}{|c|}{2010} & \multicolumn{2}{|c|}{2019} & \multicolumn{2}{|c|}{ difference } \\
\hline & in $\%$ & ranking & in $\%$ & ranking & in $p p$. & Change in ranking \\
\hline EU & 15.8 & --- & 14.1 & --- & -1.7 & --- \\
\hline Eurozone & 17.0 & --- & 14.9 & --- & -2.1 & --- \\
\hline Luxembourg & 8.7 & 6 & 1.3 & 1 & -7.4 & 5 \\
\hline Romania & 8.8 & 7 & 3.3 & 2 & -5.5 & 5 \\
\hline Italy & 5.3 & 3 & 4.7 & 3 & -0.6 & 0 \\
\hline Belgium & 10.2 & 8 & 5.8 & 4 & -4.4 & 4 \\
\hline Slovenia & 0.9 & 1 & 7.9 & 5 & 7.0 & -4 \\
\hline Poland & 4.5 & 2 & 8.5 & 6 & 4.0 & -4 \\
\hline Cyprus & 16.8 & 18 & 10.1 & 7 & -6.7 & 11 \\
\hline Greece* & 15.0 & 13 & 10.4 & 8 & -4.6 & 5 \\
\hline Portugal & 12.8 & 10 & 10.6 & 9 & -2.2 & 1 \\
\hline Ireland* & 13.9 & 12 & 11.3 & 10 & -2.6 & 2 \\
\hline Croatia & 5.7 & 4 & 11.5 & 11 & 5.8 & -7 \\
\hline Malta & 7.2 & 5 & 11.6 & 12 & 4.4 & -7 \\
\hline Sweden & 15.4 & 14 & 11.8 & 13 & -3.6 & 1 \\
\hline Spain & 16.2 & 17 & 11.9 & 14 & -4.3 & 3 \\
\hline Lithuania & 11.9 & 9 & 13.3 & 15 & 1.4 & -6 \\
\hline Denmark & 17.1 & 19 & 14.0 & 16 & -3.1 & 3 \\
\hline Bulgaria & 13.0 & 11 & 14.1 & 17 & 1.1 & -6 \\
\hline Netherlands & 17.8 & 21 & 14.6 & 18 & -3.2 & 3 \\
\hline France & 15.6 & 16 & 16.5 & 19 & 0.9 & -3 \\
\hline Finland & 20.3 & 23 & 16.6 & 20 & -3.7 & 3 \\
\hline Hungary & 17.6 & 20 & 18.2 & 21 & 0.6 & -1 \\
\hline Slovakia & 19.6 & 22 & 18.4 & 22 & -1.2 & 0 \\
\hline Czechia & 21.6 & 24 & 18.9 & 23 & -2.7 & 1 \\
\hline Germany & 22.3 & 25 & 19.2 & 24 & -3.1 & 1 \\
\hline United Kingdom* & 23.3 & 26 & 19.8 & 25 & -3.5 & 1 \\
\hline Austria & 24.0 & 27 & 19.9 & 26 & -4.1 & 1 \\
\hline Latvia & 15.5 & 15 & 21.2 & 27 & 5.7 & -12 \\
\hline Estonia & 27.7 & 28 & 21.7 & 28 & -6.0 & 0 \\
\hline Std. Dev. & 6.5 & --- & --- & 8.2 & --- & --- \\
\hline Coef. of var. & 0.45 & --- & --- & 0.63 & --- & --- \\
\hline
\end{tabular}

* - data for 2018 .

Source: own elaboration based on Eurostat data: [earn_gr_gpgr2] (accessed: October 25, 2020)

The ranking is very diverse. The top and bottom of the hierarchy include both new and old EU member states. The performance of all EU countries seems better than Eurozone economies, which means that, on average, non-Euro countries see more equal payments among men and women.

Poland ranked second in 2010, with an index amounting to $4.5 \%$, and sixth in 2019 , with a value of $8.5 \%$. The evaluation of these facts is ambiguous - unfortu- 
nately, the gender pay gap deteriorated; however, Poland still maintains a high ranking, as it is among the best countries in the EU. It is also a leader among the V4 countries, but the disparities call for a deeper analysis of the gender gap in Poland and the other Visegrad Group countries. Table 2 presents detailed yearly data on the gender pay gap in the V4 countries in the light of the EU and eurozone (as Slovakia belongs to the eurozone).

Table 2. The Gender Pay Gap in V4 countries in the light of the EU (in \%)

\begin{tabular}{lrrrrrrrrrr}
\hline & 2010 & 2011 & 2012 & 2013 & 2014 & 2015 & 2016 & 2017 & 2018 & 2019 \\
\hline EU & 15.8 & 16.2 & 16.4 & 16.0 & 15.7 & 15.5 & 15.1 & 14.6 & 14.4 & 14.1 \\
\hline Eurozone & 17.0 & 17.3 & 17.6 & 17.1 & 16.8 & 16.5 & 16.2 & 15.7 & 15.3 & 14.9 \\
\hline Poland & 4.5 & 5.5 & 6.4 & 7.1 & 7.7 & 7.3 & 7.1 & 7.0 & 8.5 & 8.5 \\
\hline Hungary & 17.6 & 18.0 & 20.1 & 18.4 & 15.1 & 14.0 & 14.0 & 15.9 & 14.2 & 18.2 \\
\hline Czechia & 21.6 & 22.6 & 22.5 & 22.3 & 22.5 & 22.5 & 21.5 & 21.1 & 20.1 & 18.9 \\
\hline Slovakia & 19.6 & 20.1 & 20.8 & 18.8 & 19.7 & 19.7 & 19.2 & 20.1 & 19.8 & 18.4 \\
\hline Average & 15.8 & 16.6 & 17.5 & 16.7 & 16.3 & 15.9 & 15.5 & 16.0 & 15.7 & 16.0 \\
\hline Std. Dev. & 7.7 & 7.6 & 7.4 & 6.6 & 6.5 & 6.7 & 6.4 & 6.4 & 5.5 & 5.0 \\
\hline Coef. of var. & 0.49 & 0.46 & 0.43 & 0.40 & 0.40 & 0.42 & 0.41 & 0.40 & 0.35 & 0.31 \\
\hline
\end{tabular}

Source: own elaboration based on Eurostat data [earn_gr_gpgr2] (accessed: October 25, 2020)

Analysis of the data presented in Table 2 shows that Poland remained a leader, with the lowest GPG index among all the V4 countries during the whole analyzed period. However, the payment inequalities deteriorated most significantly - from $4.5 \%$ in 2010 to $8.5 \%$ in 2020 . During the same period, the GPG in Slovakia remained relatively stable (at an average level of around 19.6\%). It fell slightly in Czechia (from $21.6 \%$ in 2010 to $18.9 \%$ in 2019), and it fluctuated in Hungary (20.8\% in 2012, 14\% in 2015 and 2016, and 18.2\% in 2019).

The next step of the research was to investigate the share of women employed in managerial positions in the V4 economies. The total data (regardless of the age of the employees) is presented in Table 3.

Table 3. Women Employed in Managerial Positions (all ages)

\begin{tabular}{lrrrrrrrrrr}
\hline & 2010 & 2011 & 2012 & 2013 & 2014 & 2015 & 2016 & 2017 & 2018 & 2019 \\
\hline EU & 33.3 & 32.7 & 32.8 & 32.1 & 31.7 & 31.9 & 32.6 & 32.6 & 33.0 & 33.5 \\
\hline Eurozone & 33.4 & 32.1 & 32.2 & 31.2 & 30.6 & 30.4 & 31.3 & 31.3 & 31.6 & 32.1 \\
\hline Poland & 35.6 & 38.0 & 37.8 & 37.8 & 38.8 & 40.2 & 41.2 & 41.2 & 42.5 & 43.0 \\
\hline Hungary & 36.5 & 40.4 & 38.9 & 40.8 & 39.8 & 40.5 & 39.4 & 39.3 & 38.6 & 38.9 \\
\hline Czechia & 27.7 & 25.7 & 26.2 & 27.2 & 27.9 & 29.5 & 25.4 & 24.7 & 26.8 & 26.8 \\
\hline Slovakia & 34.6 & 30.9 & 33.2 & 32.7 & 30.0 & 31.3 & 35.0 & 32.7 & 32.1 & 33.7 \\
\hline Average & 33.6 & 33.8 & 34.0 & 34.6 & 34.1 & 35.4 & 35.3 & 34.5 & 35.0 & 35.6 \\
\hline Std. Dev. & 4.0 & 6.7 & 5.8 & 6.0 & 6.1 & 5.8 & 7.1 & 7.5 & 6.9 & 7.0 \\
\hline Coef. of var. & 0.12 & 0.20 & 0.17 & 0.17 & 0.18 & 0.16 & 0.20 & 0.22 & 0.20 & 0.20 \\
\hline
\end{tabular}

Source: own elaboration based on Eurostat data [tqoe1c2] (accessed: October 30, 2020)

Considering the share of women holding managerial positions, Poland became a leader among the V4 countries (overlapping Hungary) in 2016. The index increased from $35.6 \%$ in 2010 to $43 \%$ in 2019 . At the same time, Hungary and 
Slovakia, which were at a similar starting point (close together with Poland), fluctuated slightly but remained relatively constant - higher for Hungary and lower for Slovakia. Czechia also remained stable, but at a significantly lower level, around $27 \%$, also below the EU average. It is important to highlight that the shares of women employed in managerial positions in Poland, Hungary, and Slovakia were above the EU average. However, it can be concluded that the differences between the V4 countries were significant, confirmed by the standard deviation and coefficient of variation (the variation increased over the last decade).

The next step was to check the employment level of relatively young women in managerial positions. The results are presented in Table 4.

Table 4. Women Employed in Managerial Positions (up to 39 years of age)

\begin{tabular}{lrrrrrrrrrr}
\hline & 2010 & 2011 & 2012 & 2013 & 2014 & 2015 & 2016 & 2017 & 2018 & 2019 \\
\hline EU & 37.0 & 37.8 & 37.1 & 36.1 & 35.8 & 35.5 & 36.7 & 36.4 & 36.9 & 37.1 \\
\hline Eurozone & 37.3 & 37.8 & 37.4 & 35.9 & 35.1 & 34.6 & 35.8 & 35.5 & 36.0 & 36.5 \\
\hline Poland & 39.1 & 40.3 & 38.9 & 39.4 & 39.7 & 40.9 & 44.0 & 42.5 & 44.0 & 43.8 \\
\hline Hungary & 36.6 & 38.0 & 37.7 & 40.5 & 43.4 & 41.0 & 33.6 & 35.1 & 35.8 & 33.2 \\
\hline Czechia & 30.1 & 25.9 & 24.8 & 27.0 & 30.0 & 30.2 & 24.1 & 25.5 & 31.0 & 29.4 \\
\hline Slovakia & 35.5 & 29.8 & 33.7 & 35.0 & 32.6 & 34.3 & 34.7 & 33.6 & 31.4 & 35.3 \\
\hline Average & 35.3 & 33.5 & 33.8 & 35.5 & 36.4 & 36.6 & 34.1 & 34.2 & 35.6 & 35.4 \\
\hline Std. Dev. & 3.8 & 6.8 & 6.4 & 6.1 & 6.2 & 5.3 & 8.1 & 7.0 & 6.0 & 6.1 \\
\hline Coef. of var. & 0.11 & 0.20 & 0.19 & 0.17 & 0.17 & 0.14 & 0.24 & 0.20 & 0.17 & 0.17 \\
\hline Source: own & & & & & & & & & &
\end{tabular}

Source: own elaboration based on Eurostat data [tqoe1c2] (accessed: October 30, 2020)

Poland was a leader again, exceeding both the other V4 countries and the EU average. Moreover, the increase in the share of young women in managerial positions rose most significantly, from $39 \%$ to almost $44 \%$. On average, it is much better than in the whole EU, where it remained stable at around $37 \%$. The data for Hungary fluctuated greatly, like Czechia and Slovakia, but, ultimately, they ended up below their starting points. However, the differences between countries were, on average, smaller than for women of all ages.

To make the picture complete, the employment of women over 50 years in managerial positions was investigated as the last part of the research, and the results are presented in Table 5.

Table 5. Women Employed in Managerial Positions (age over 50 years)

\begin{tabular}{lrrrrrrrrrr}
\hline & 2010 & 2011 & 2012 & 2013 & 2014 & 2015 & 2016 & 2017 & 2018 & 2019 \\
\hline EU & 30.5 & 29.0 & 29.3 & 29.2 & 28.8 & 29.6 & 30.0 & 29.7 & 29.3 & 30.0 \\
\hline Eurozone & 30.7 & 27.8 & 28.5 & 28.1 & 27.5 & 27.9 & 28.7 & 28.2 & 27.8 & 28.7 \\
\hline Poland & 31.8 & 35.7 & 34.8 & 35.4 & 36.9 & 39.2 & 37.3 & 37.9 & 40.5 & 40.0 \\
\hline Hungary & 33.6 & 42.8 & 37.7 & 41.7 & 42.1 & 46.7 & 44.2 & 41.6 & 42.9 & 41.1 \\
\hline Czechia & 24.9 & 26.2 & 27.3 & 27.6 & 27.0 & 28.1 & 27.1 & 27.5 & 23.9 & 23.4 \\
\hline Slovakia & 33.9 & 32.5 & 34.4 & 30.3 & 29.2 & 31.3 & 32.7 & 30.1 & 31.4 & 33.9 \\
\hline Average & 31.1 & 34.3 & 33.6 & 33.8 & 33.8 & 36.3 & 35.3 & 34.3 & 34.7 & 34.6 \\
\hline Std. Dev. & 4.2 & 6.9 & 4.4 & 6.2 & 7.0 & 8.3 & 7.2 & 6.6 & 8.7 & 8.1 \\
\hline Coef. of var. & 0.14 & 0.20 & 0.13 & 0.18 & 0.21 & 0.23 & 0.20 & 0.19 & 0.25 & 0.23 \\
\hline
\end{tabular}

Source: own elaboration based on Eurostat data [tqoe1c2] (accessed: October 30, 2020) 
It is important to note that the situation is different when it comes to women over 50. Hungary recorded the best performance, followed by Poland and Slovakia. Although Slovakia was a leader at the beginning of the investigated period, in 2010, it lost its position to Hungary and Poland in 2011. Moreover, while the situation in Slovakia was relatively stable throughout the whole period, in Hungary and Poland, the share increased. Czechia's performance was the worst throughout the entire period. The differences between the V4 countries were significant, verified by the standard deviation values and the coefficient of variation.

\section{Summary}

The gender pay gap differed significantly in the analyzed period in the V4 economies. Poland recorded the best performance among them, coming second in the European Union in 2010 and sixth in 2019. Unfortunately, the drop in the European ranking was caused by the GPG increase - from $4.5 \%$ to $8.5 \%$. In 2019 , Hungary, Slovakia, and Czechia were in 21 st, 22nd, and 23rd positions, respectively. Their positions in the EU ranking in 2019 were similar. The GPG in these economies oscillated around $18 \%$, far below the EU average.

Poland was also a leader in the employment of women in managerial positions. The share of women (of all ages) among all managers increased from $35.6 \%$ in 2010 to $43 \%$ in 2019 , which was much better than in the EU, on average. Hungary also recorded a higher share than the EU average. However, Czechia and Slovakia were far below the EU average. Similar effects were recorded for relatively young women, i.e., under 40. Slightly different results were obtained for women over 50 years of age. Nevertheless, the Polish and Hungarian economies employed more women in managerial positions than Czechia and Slovakia.

To sum up, we can conclude that Poland presented a good performance, with a relatively low gender pay gap. Additionally, the share of women in managerial positions in Poland rose and was much higher than the EU average. Hungary, Czechia, and Slovakia should improve their performances, especially regarding the gender pay gap, while Czechia and Slovakia should encourage the employment of women in managerial positions.

The empirical investigation did not allow us to reject the first hypothesis for Poland only, although it should be rejected for the other V4 economies. The second hypothesis should be rejected for all countries.

\section{References}

17 Goals to Transform Our World. (2020). United Nations. https://www.un.org/ sustainabledevelopment/ (accessed: October 20, 2020). 
Adelekan, A. M. \& Bussin, M. H. R. (2018). Gender Pay Gap in Salary Bands Among Employees in the Formal Sector of South Africa. SA Journal of Human Resource Management, 16, article a1018. https://doi.org/10.4102/ sajhrm.v16i0.1018

Aláez-Aller, R., Longás-García, J. C. \& Ullibarri-Arce, M. (2011). Visualising Gender Wage Differences in the European Union. Gender, Work and Organization, 18(suppl. 1), e49-e87.

Arulampalam, W., Booth, A. L. \& Bryan, M. L. (2007). Is There a Glass Ceiling over Europe? Exploring the Gender Pay Gap across the Wage Distribution. Industrial and Labor Relations Review, 60(2), 163-186.

Bando, R. (2019). Evidence-Based Gender Equality Policy and Pay in Latin America and the Caribbean: Progress and Challenges. Latin American Economic Review, 28(1), 1-23.

Bayard, K., Hellerstein, J., Neumark, D. \& Troske, K. (1999). New Evidence on Sex Segregation and Sex Difference in Wages from Matched EmployeeEmployer Data. NBER Working Paper, 7003.

Becker, G. S. (1957). The Economics of Discrimination, $2^{\text {nd }}$ ed. Chicago: University of Chicago Press.

Becker, G. S. (1985). Human Capital, Effort, and the Sexual Division Labor. Journal of Labor Economics, 3(1), 33-58.

Bergmann, B. (1974). Occupational Segregation, Wages, and Profits when Employers Discriminate by Race or Sex. Eastern Economic Journal, 1(2), 103-110.

Bhorat, H. \& Goga, S. (2013). The Gender Wage Gap in Post-Apartheid South Africa: A Re-Examination. Journal of African Economies, 22(5), 827-848.

Black, S. E. \& Brainerd, E. (2004). Importing equality? The Impact of Globalization on Gender Discrimination. Industrial and Labor Relations Review, 57(4), 540-559. https://doi.org/10.1177\%2F001979390405700404

Blau, F. D. (1977). Equal Pay in the Office. Lexington, MA: Lexington Books.

Blau, F. D. \& Kahn, L. M. (2007). The Gender Pay Gap: Have Women Gone as far as They Can? Academy of Management Perspectives, 21(1), 7-23.

Dolado, J. J., García-Peñalosa, C. \& Tarasonis, L. (2020). The Changing Nature of Gender Selection into Employment over the Great Recession. Economic Policy, 35(104), 635-677.

Domańska, A., Żukowska, B. \& Zajkowski, R. (2019). Sustainable Development versus Gender Gap - Do Women Matter? Problemy Ekorozwoju, 14(2), 129-142.

Fadoš, M. \& Bohdalová, M. (2019). Unemployment Gender Inequality: Evidence from the 27 European Union Countries. Eurasian Economic Review, 9(3), 349-371.

Galy-Badenas, F. \& Croucher, S. M. (2016). Men and Women in Positions of Responsibility: A Qualitative Analysis of Organizational Readiness in France and Finland. Journal of Intercultural Communication, 41. 
Jakubowska, U. \& Kaniasty, K. (2015). Predictors of Political Participation in Poland: Gender and Period Effects in the Context of Political Transformation. Československá Psychologie, 59(1), 79-90.

Leythienne, D. \& Ronkowski, P. (2018). A Decomposition of the Unadjusted Gender Pay Gap Using Structure of Earnings Survey Data. Luxembourg: Publications Office of the European Union.

Marcu, L. \& Tănase, C. L. (2018). Employment Rate and Gender Employment Gap in Romania in the Context of Europe 2020 Strategy. Ovidius University Annals. Economic Sciences Series, 18(1), 92-97.

Marilyn, B. \& Olawale, O. (2017). Achieving the Millennium and Sustainable Development Goals in Africa: What Role for Female Social Workers. Gender and Behaviour, 15(2), 9088-9100.

Maume, D. J., Heymann, O. \& Ruppanner, L. (2019). National Board Quotas and the Gender Pay Gap among European Managers. Work, Employment and Society, 33(6), 1002-1019.

Norrander, B. (1999). The Evolution of The Gender Gap. Public Opinion Quarter$l y, 63(4), 566-576$.

North, A. (2010). MDG 3 and the Negotiation of Gender in International Education Organisations. Compare: A Journal of Comparative \& International Education, 40(4), 425-440. https://doi.org/10.1080/03057925.2010.490363

Oczki, J. (2016). Gender Pay Gap in Poland. Ekonomia Międzynarodowa, 14, 106-113. https://doi.org/10.18778/2082-4440.14.01

Ofisi, M. \& Lukamba, M. T. (2020). Closing the Gender Gap through ICT in Small Scale Farming: Towards Achieving Sustainable Development Goals. Gender and Behaviour, 18(4), 16687-16697.

Srinivas, S. (2007). Social Attitudes and the Gender Pay Gap in the USA in Recent Years. International Journal of Social Economics, 34(4), 268-275. https://doi.org/10.1108/03068290710734226

The gender pay gap situation in the EU. (2020). European Commission. https:// ec.europa.eu/info/policies/justice-and-fundamental-rights/gender-equality/ equal-pay/gender-pay-gap-situation-eu_en (accessed: October 25, 2020).

van Mensvoort, C., Kraaykamp, G., Meuleman, R. \& van den Brink, M. (2020). A Cross-Country Comparison of Gender Traditionalism in Business Leadership: How Supportive Are Female Supervisors? Work, Employment and Society, 35(4), 793-814.

Women remain outnumbered in management. (2020). Eurostat, March 3. https://ec.europa.eu/eurostat/web/products-eurostat-news/-/edn-20210305-2 (accessed: October 25, 2020)

Zawisza, M., Luyt, R. \& Zawadzka, A. (2012). Ambivalence Toward Men: Comparing Sexism Among Polish, South African and British University Students. Sex Roles, 66(7-8), 453-467. 